\title{
立体映像の視差角を等分する中間画像の挿入による融像限界の变化
}

\author{
采女智津江 $*^{1}$ ，小嶌 健仁 $*^{1}$ ，杉浦 明弘 $*^{1}$ ，森田 一三 $*^{2}$, 宮尾 克 $*^{1}$ \\ *1 名古屋大学情報科学研究科 \\ $*^{2}$ 日本赤十字豊田看護大学
}

\section{Change in the Fusion Limit by Insertion of a Middle Image Equally Dividing the Parallactic Angle of 3D Stereoscopic Images}

\author{
Chizue UNEME*1, Takehito KOJIMA*1, Akihiro SUGIURA*1, Ichizo MORITA*2 and Masaru MIYAO*1 \\ *l Graduate School of Information Science, Nagoya University \\ *2Japanese Red Cross Toyota College of Nursing
}

\begin{abstract}
Objectives: The purpose of this study was to identify and clarify the requirements for 3D stereoscopic images that do not cause viewing discomfort to the human eye even when the protrusion distance is large.

Methods: A total of 140 healthy men and women aged 14 to 79 years participated in this study. We first measured the fusion limits in these participants using two 3D stereoscopic images. We then measured the expansion of the fusion limit by inserting a middle image in a region located equally parallax from the two images.

Results: The results showed that the fusion limits were significantly expanded $(p<0.01)$ after inserting the middle image.

Conclusions: Insertion of middle images with parallax can extend the fusion limit. This method was shown to be an effective for viewing 3D stereoscopic images without causing discomfort.
\end{abstract}

Key words: 3D stereoscopic image（3D 立体映像）, middle image (中間画像), fusion limit (融像限界), depth perception (奥行き感覚), convergence (輻輳運動), accommodation（焦点調節）

1. 緒言

近年の 3D 技術の普及発展には目を見張るものがある が, 映画や TV の分野での 3D 立体映像（以後, 立体映像） 市場は, 低迷している感があるのは否めない。普及の障 害となっている要因の一つには, 立体映像の観視にとも なう，めまいや頭痛，眼精疲労など身体への影響の原因 が明確になっていないことが考えられるが，これら視覚 愁訴の原因については, 立体映像観視時には, 水晶体調 節（ピント）の焦点と, 輻輳（両眼の視軸の交点）の焦 点が異なるとする調節輻輳矛盾説が一般的であった。し かし，共同研究者らの先行研究により，若年層に打いて は，調節と輻輳の不一致は生じていないことが示されて

受付 2016 年 6 月 21 日, 受理 2016 年 10 月 24 日 Reprint requests to: Chizue UNEME

Graduate School of Information Science, Nagoya University, 1-1 Hiraka-gakuendai, Inzai City, Chiba 270-1695, Japan

FAX: +81(476)98-1011

E-mail: cuneme@juntendo.ac.jp
いる（1-3）。また, MacKenzie ら（4）は， 2 枚のディスプ レイにそれぞれ異なるコントラスト勾配を持った画像を 表示することで，両者の間の空間に調節と輻輳の乘離が 少ない立体映像を知覚させることが可能と述べている。

立体映像の普及の障害になっているもら一つの要因 は, 立体映像のコンテンッは飛出しが控えめに抑放られ, 人々が期待していたような迫力のある映像とは程遠いも のになってしまっていることがあげられる (5)。3D ンン ソーシアムによる「人に優しい 3D 普及のための 3DC 安 全ガイドライン」（2010 年 4 月改訂）（6）では，立体映 像の快適視差範囲は視差角（人間が物体を見るときに, 左眼と右眼で発生する角度差) $\pm 1.0^{\circ}$ 以内とされている。 日本に打ける立体映像コンテンッやハードウェアは, こ の視差角以下に設定されているのであるが，この数值に 従って立体映像を作った場合, 特に飛出し側については, 視距離 $1 \mathrm{~m}$ で, $22 \mathrm{~cm}$ 程度の飛出しであり, ダイナミック な魅力ある立体映像を提供できない。この快適視差範囲 についても， $1.0^{\circ}$ といら数值 (7) が妥当であるかといら 問題がある。この件に関しても, 共同研究者らによって, 
視差角 $2.0^{\circ}$ までは $80 \%$ 以上の人が努力することなく見 えているといら結果を得ているからである $(1-3,8)$ 。

本研究では, 飛出し量が大きくても多くの人が無理な く見ることができる立体映像の条件を把握するため, ディ スプレイ面に表示された画像と飛出し画像の間に中間画 像を挿入することによる, 融像限界の拡張量について検 証した。また，中間画像の効果は年齢や挿入枚数によっ てどのように変化するかについても着目し検証を行った。

\section{2. 用語の解説}

\section{1 融像}

人間の眼は左右に $60 \mathrm{~mm}$ 程度離孔て 2 つることか ら, 左右の眼の網膜像にはずれが生じる (両眼視差)。そ れ艺れの網膜像は, 眼球の奥から出る視神経によって大 脳の後頭葉にある視覚野に届けられ, 融合さ水て単一の 映像として認識される。このように左右眼の網膜像を単 一に映像化することを融像と呼ぶが, この過程で, 左右 の網膜像のずれを脳が解析することによって立体的に見 えたり，奥行き情報をつかんだりすることができる（9）。

\section{2 水晶体調節}

水晶体は, カメラでいらとレンズに当たる。カメラの レンズは, レンズと受光面の距離を変化させることで対 象に焦点を合わせるが，ヒトの水晶体は，近くを見ると きは厚くなり，遠くを見るときは薄くなることで焦点距 離を変化させ焦点を合わせる。水晶体の厚さは, 毛梯体 筋の弛緩（薄くなる）と緊張（厚くなる）により変化し， 注視点に焦点を合わせている。

\section{3 融像限界}

両眼視差のある映像を 1 つの立体像として融像できる 限界には個人差があるが，一般に空間上のある一点を注 視して融像するときに, 左右の眼に映った網膜像にずれ があっても, パナムの融像領域 (panum's fusion area) と 呼ばれる範囲では, 視覚のメカニズムが働き二重像にな らず融像できる。我々の眼は, 左右に $60 \mathrm{~mm}$ 程度離孔て いるため, 水平方向に, 両眼の網膜上での結像部位が一 致する点が集まってできる軌跡（ホロプター円）が描け る。パナムの融像領域はこの前後の空間であり, 左右眼 像を融像できる許容範囲ともいわれる。本研究では融像 可能な最大の両眼視差 (角度)を融像限界と呼ぶ $(8,10)$ 。

\section{4 中間画像}

本研究では, ディスプレイ面と飛出し視差角の位置に 画像を表示した状態を初期画像と呼ぶ。例光ば, 飛出し 視差角 $1.0^{\circ}$ の立体映像の場合, ディスプレイ面と飛出

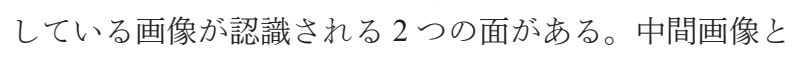
は，この 2 つの面の間に挿入する画像である。各中間画 像は, 初期画像の 2 面の距離を, 扦入する画像の枚数 +1 で割った位置に配置され, 大きさも画面位置の画像
表 1 実験における年齢層の区分

\begin{tabular}{ccccc}
\hline 年齢層 & 年齢区分 & 人数 & 平均 $($ 歳) & 標準偏差 \\
\hline 若年 & $14-29$ & 38 & 20.7 & \pm 4.2 \\
壮年 & $30-44$ & 25 & 39.1 & \pm 4.3 \\
中年 & $45-64$ & 46 & 52.4 & \pm 5.6 \\
高年 & $65-79$ & 28 & 71.6 & \pm 4.3 \\
\hline
\end{tabular}

と, 飛び出し視差角の画像の間のサイズである。したがっ て, 中間画像の枚数が増えるごとに画像間の距離が小さ くなり，中間画像を含めた全体の映像は，ピラミッド状 の図形になる。

\section{3. 方法}

\section{1 実験参加者}

本研究の実験参加者は, 14 歳から 79 歳の健康な男女 137 名で, 視機能の変化に応じて若年, 壮年, 中年, 高 年の 4 グループに分け, 年齢による融像限界への影響に ついて比較・検証した。若年は十分な調節力があり視機 能の低下がない層, 壮年は調節力は少し弱っているが生 活に支障がない層，中年は近見作業にやや支障があり老 眼鏡の必要な人もいる層, 高年は老視で，矯正なしには 近業ができない層として区分した（表 1)。実験参加者 には，事前に十分にインフォームドコンセントを行い， 同意を得ている。な拉, 本実験は名古屋大学情報科学研 究科の倫理審査委員会の承認を得て実施した。

\section{2 実験デザイン}

立体映像に中間画像を挿入することによる融像限界の 変化を測定するために，次の手順で実験を行った。先行 研究 (8) で示されたように, 視差角 $2.0^{\circ}$ を超光ると, 融像できない人の割合が増加することから, 視差角 $2.0^{\circ}$ を基準に実験を行った。

1）中間画像を挿入していない立体映像の融像限界の測定

ディスプレイ面に表示された画像に, 視差角 $2.0^{\circ}$ の 画像を重社た映像（以下，初期画像）を見せ，融像でき なかった場合, 視差角を 0.1 刻みに下げていき，立体 映像として知覚できたとき，その視差角を融像限界とし た。視差角 $2.0^{\circ}$ の初期画像が知覚できた場合は, 視差 角を $1.0^{\circ}$ 刻みで上げていき立体映像として知覚できな い角度まで上げた後, 0.1 刻みで下げていき, 立体映像 として知覚できたとき, 融像限界とした。

知覚の可否の基準は，はっきりと立体映像として見兄 ていない場合，すなわち「济やけている」「二重として 見光る」、「立体映像には見光ない」等はすべて知覚でき ないと判断した。

\section{2）扦入する中間画像の枚数の決定}

各実験参加者の融像限界の初期画像に, 中間画像 1, 2, 6，14 枚を插入した映像を提示し（図 1)，一番はっきり 見える枚数を選択させた。 


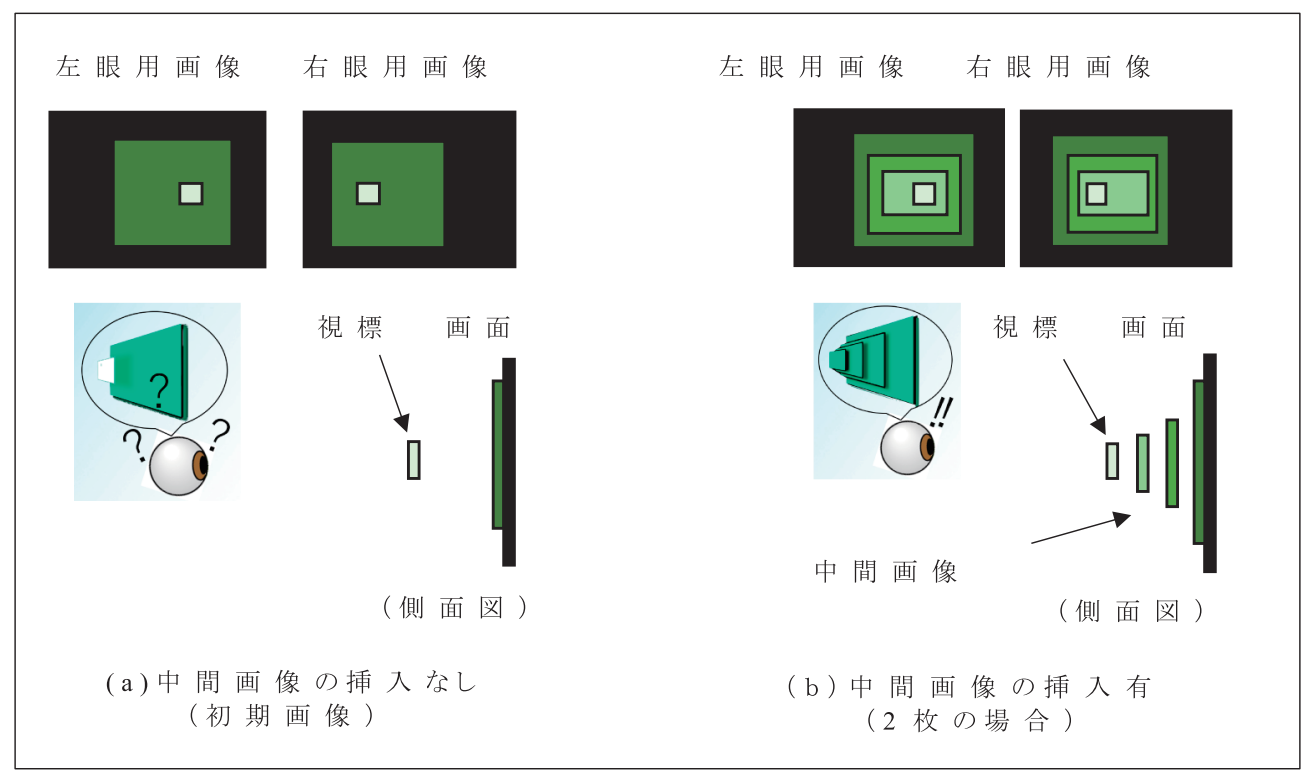

図 1 初期画像および中間画像の模式図概要

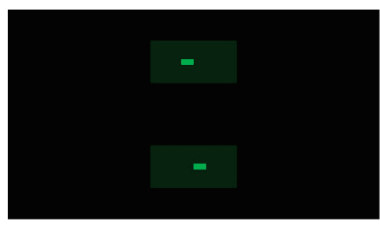

$1^{\circ}$

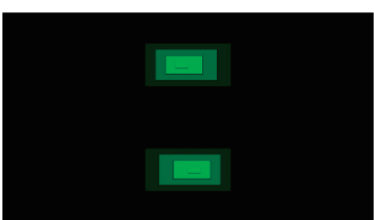

$1^{\circ}$

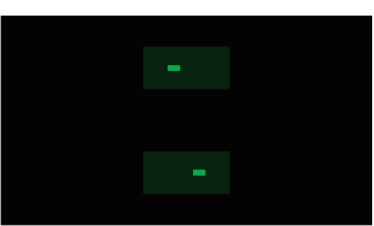

$2^{\circ}$

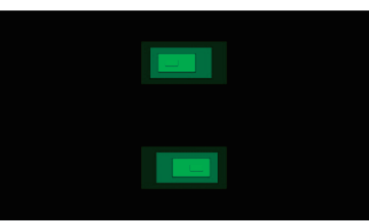

$2^{\circ}$

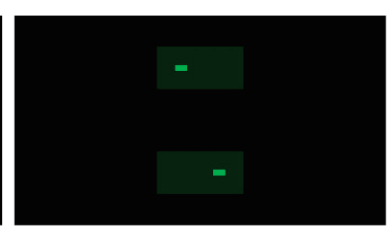

$3^{\circ}$

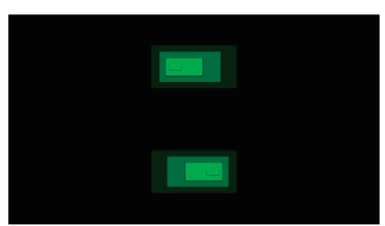

$3^{\circ}$

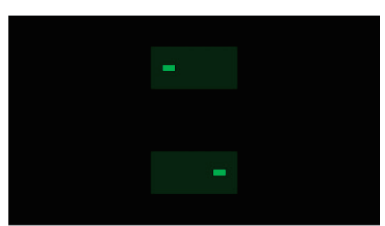

$4^{\circ}$

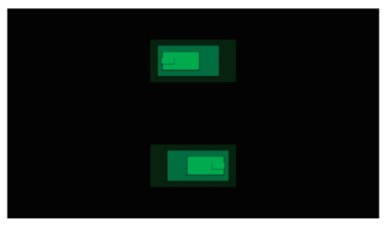

$4^{\circ}$

図 2 実験で使用したコンテンツ。（上）中間画像挿入前（初期画像）の画像。（下）中間画像扱入後の画像。

\section{3）選択した中間画像の枚数での融像限界の測定}

初期画像に，2）で選択した枚数の中間画像を挿入し た視差角 $3.0^{\circ}$ の映像を提示し, 融像限界の測定は 1) と 同様に行った。試行開始を $3.0^{\circ}$ とたのは, 中間画像 を挿入することで視差角 $2.0^{\circ}$ を超える実験参加者が増 えることが予想されたためである。

\section{3 実験コンテンツ}

本実験で使用したコンテンッは，ディスプレイ上に表 示された画像に対し， $0.1^{\circ}$ 刻みで視差角を $0.0^{\circ} \sim 8.0^{\circ}$ まで変化させる初期画像を用意した。それぞれの初期画 像に対し，1，2，6，14 枚の中間画像を挿入する 4 種の 画像を作成し，合計 405 枚を使用した。ピクセル数は $1920 \times 1080$, 画像の枠線は 1 ピクセルの黒である。最前 面の画像の色は緑 RGB（0：255：0）であり，最背面の
画像の色はRGB（0：40：0）である。緑を使用した理 由は，赤や黄色に比べて視認性が高いためである。

実験に使用したコンテンッを（図 2）に示す。（上） は中間画像を挿入しない初期画像，（下）は 2 枚の中間 画像を挿入したときの映像である。トップアンドボトム 方式で表示しているため，偏光メガネなしの状態では， 上半分と下半分が重なった状態で表示される。

\section{4 実験環境}

実験は，暗室内で行った。ディスプレイからの視距離 は $1 \mathrm{~m}$ とし，座った状態で実験を行った（図 3)。ディ スプレイはRDT233-WX (MITSUBISHI)，2 眼式。3D 表示は円偏光方式であり, 立体映像観視時には円偏光メ ガネを使用した。 


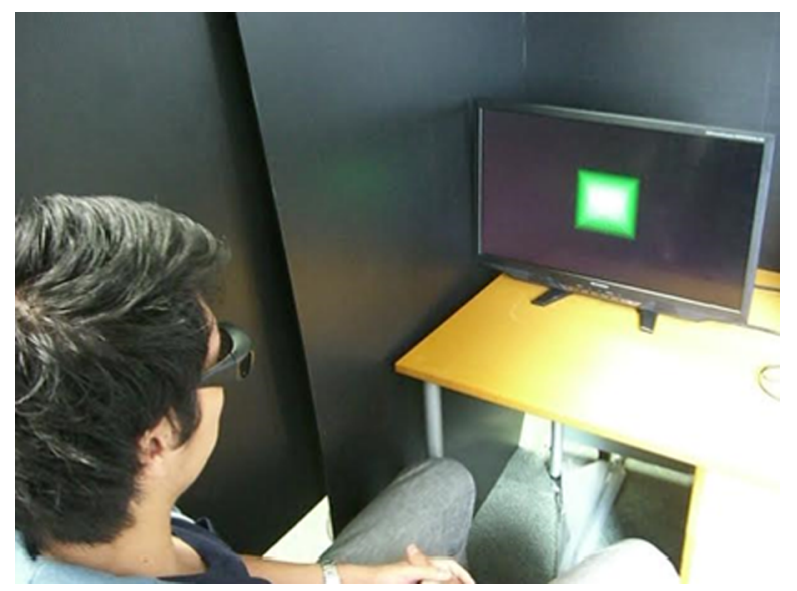

図 3 実験環境

\section{5 分析方法}

加齢に伴い水晶体が硬化し, 調節能力が衰兄ていくた め, 年齢によって融像限界に差があるかを 4 グループに 分けて比較・検証を行った。年齢層の分け方は, 表 1 に 示したと打りである。中間画像の影響を調べるために, 初期画像と中間画像挿入時の枚数 $(1,2 ， 6,14$ 枚 $)$ ご との融像限界の平均值について, 対応のある $\mathrm{t}$ 検定を 行った。中間画像を插入することで融像限界が有意浪拡 張することが認められたため，年齢別掞よび枚数別の融 像限界の拡張值に着目して, 二元配置分散分析 Scheffe の方法によって群間の多重比較分析を行った。ただし， 標本数の項目によっては 0 の区分が生じたため, 年齢群 は, 若年と壮年を合わせて若・壮年, 中年, 高年の 3 群 間，中間画像の枚数は 1 枚， 2 枚と 6 枚を合わせ $2 \cdot 6$ 枚, 14 枚の 3 群間にして，二元配置分散分析を行った。

\section{4. 結 果}

\section{1 枚数別中間画像扱入前・後の融像限界の比較}

初期画像之中間画像扦入時の融像限界は, 4 種の枚数 のいずれに执いても有意 $(\mathrm{p}<0.01)$ 飞拡張していた (図 4)。また，実験参加者が主観的に評価した「もっと もよく見光た」中間画像の枚数は，1枚と 14 枚が多く, 2 枚, 6 枚は 1 枚と比較して減少傾向にあり, 最大枚数 がもっとも高い割合といら結果であった（表 2)。

\section{2 年齢別中間画像挿入前・後の融像限界の比較}

年齢別に中間画像挿入前・後の融像限界を比較したと ころ，どの年齢層において子融像限界が有意 $(\mathrm{p}<0.01)$ に拡張していた（図 5)。

\section{3 枚数別融像限界拡張值の比較}

融像限界に抢敄る中間画像の枚数ごとの拡張值に差が あるか比較した。枚数ごとの融像限界の平均拡張値を 表 3 亿示し, 多重比較の結果を表 4 亿示す。中間画像の $\mathrm{p}$ 值が 0.05 を上回ったため, いずれの枚数の組み合わせ

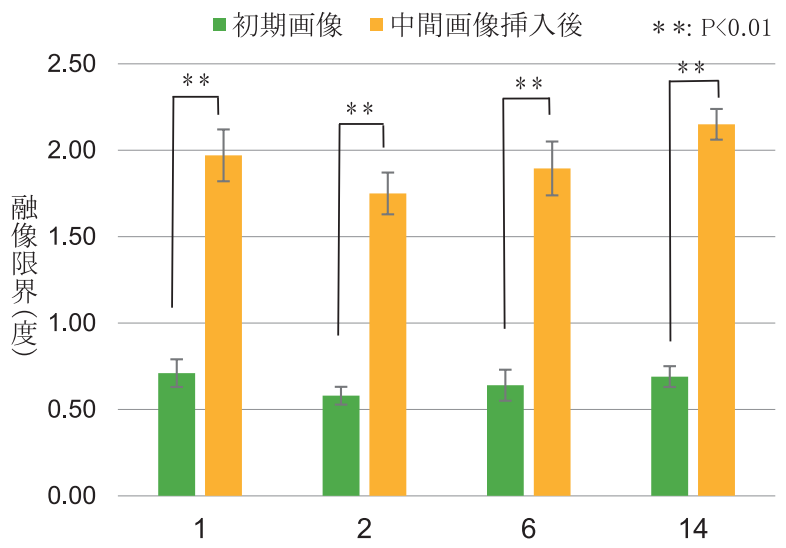

図 4 枚数別：中間画像挿入前・後の融像限界の比較

表 2 視標がもっともよく見えた中間画像の枚数

\begin{tabular}{ccccc}
\hline 中間画像の枚数 & 1 & 2 & 6 & 14 \\
\hline 選択者数 & 38 & 22 & 20 & 57 \\
$\%$ & 28 & 16 & 15 & 42 \\
\hline
\end{tabular}

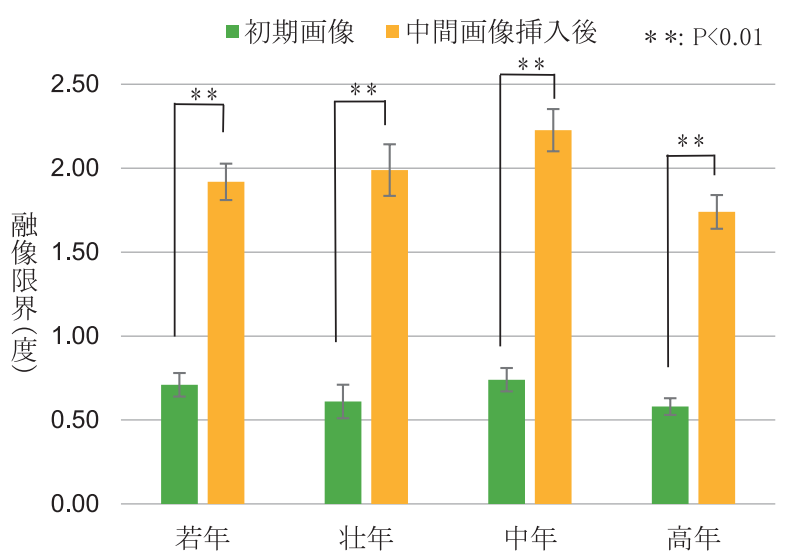

図 5 年齢層別：中間画像挿入前・後の融像限界の比較

においても有意な值の拡張はなかったが, 14 枚がもっ とも拡張量が大きかった。

\section{4 年齢層別融像限界拡張値の比較}

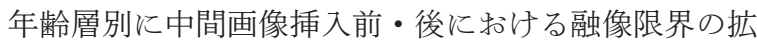
張値を比較した。年齢層ごとの融像限界の平均拡張値を 表 5 亿示し, 分析の結果を表 6 亿示す。各年齢群間のい ずれの場合も有意な差はなかった $(\mathrm{p}>0.05)$ 。

\section{5. 考察}

\section{1 中間画像扱入と融像限界との関連}

立体映像に視差角を等分する $1,2,6,14$ 枚の中間画像 を挿入し，融像限界の拡張を検証した。実験の結果す心゙ ての実験参加者で融像限界が拡張した。挿入する前の融 像限界の平均値の $0.6^{\circ}$ (飛出し距離 $13.9 \mathrm{~cm}$ ) から, 挿入 後は平均 $2.0^{\circ}$ (飛出し距離 $35.0 \mathrm{~cm}$ ) 飞拡張して抒り, ま 
表 3 枚数別: 中間画像挿入前 - 後における融像限界平均拡張值

\begin{tabular}{cc}
\hline 枚数 & 拡張値 (度) \\
\hline 1 & $1.26 \pm 0.63$ \\
2 & $1.17 \pm 0.49$ \\
6 & $1.26 \pm 0.53$ \\
14 & $1.46 \pm 0.59$ \\
全 & $1.33 \pm 0.59$ \\
\hline
\end{tabular}

表 4 枚数別：融像限界拡張値に対する多重比較

\begin{tabular}{cccc}
\hline \multirow{2}{*}{ 比較対象群 } & \multirow{2}{*}{ 平均值の差 } & \multicolumn{3}{c}{ Schffe の方法 } \\
\cline { 3 - 4 } & & $\mathrm{F}$ 値 (自由度 1,2$)$ & $\mathrm{p}$ 值 \\
\hline $1 \cdot 2$ & 0.087 & $0.102(3,133)$ & 0.96 \\
$1 \cdot 6$ & 0.000 & $0.000(3,133)$ & 1.00 \\
$1 \cdot 14$ & -0.203 & $0.907(3,133)$ & 0.44 \\
$2 \cdot 6$ & -0.087 & $0.077(3,133)$ & 0.97 \\
$2 \cdot 14$ & -0.290 & $1.291(3,133)$ & 0.28 \\
$6 \cdot 14$ & -0.203 & $0.591(3,133)$ & 0.62 \\
\hline
\end{tabular}

表 5 年齢層別：中間画像挿入前・後の融像限界の平均拡張値

\begin{tabular}{cc}
\hline 年齢層 & 拡張値 $($ 度 $)$ \\
\hline 若年 & $1.21 \pm 0.56$ \\
壮年 & $1.38 \pm 0.44$ \\
中年 & $1.49 \pm 0.70$ \\
高年 & $1.16 \pm 0.45$ \\
全 & $1.33 \pm 0.59$ \\
\hline
\end{tabular}

\section{表 6 枚数別：融像限界拡張值に対する多重比較}

\begin{tabular}{lrccc}
\hline \multirow{2}{*}{ 比較対象群 } & \multirow{2}{*}{ 平均值の差 } & \multicolumn{3}{c}{ Scheffe の方法 } \\
\cline { 3 - 5 } & & $\mathrm{F}$ 值 (自由度 1,2$)$ & $\mathrm{p}$ 值 \\
\hline 若年一壮・中年 & -0.231 & $2.108(2,128)$ & 0.13 \\
若年一高年 & 0.080 & $0.182(2,128)$ & 0.83 \\
壮一中・高年 & 0.310 & $2.480(2,128)$ & 0.09 \\
\hline
\end{tabular}

た,いずれの枚数においても融像限界は有意に拡張した。 大島ら（10）の先行研究では, ある視差角をもつ 2 枚 の図形だと $0.3^{\circ}$ 程度の視差角で融像限界を超えてしま らが，2枚の間に補助画像を入れることで融像限界が拡 張した。本研究の結果に拈いても, 中間画像の存在で, 融像限界が拡張したことから, 大島らの先行研究を支持 しており，また大島らの使用したランダムドットステレ オグラム（RDS）に限らず，左右像を分離する形式の立 体映像に打いても中間画像の効果を確認できた。な抏, 大島らの実験は，実験参加者が少数であったが，実験参 加者が多数である本研究により, 中間画像が融像限界を 拡張する効果について一般化できたと考觉る。

\section{2 中間画像の枚数と融像限界拡張との関連}

中間画像の枚数別沶よび年齢別に分析を行ったとこ ろ, 融像限界の拡張值に有意差はなかったが, 枚数の増 加により融像限界の拡張值が大きくなる傾向が見られ
た。また，実験参加者が「もっともよく見えた」と答え た枚数は 14 枚（57人）で最大枚数がよく見えていた （表 2）。大島ら（10）は，中間画像の枚数が多い注ど融 像限界が拡張したと述べて抢り，さらに，中間画像を挿 入することにより, 融像限界が拡張する機序について, 3D 画像の呈示時間を短くして実験参加者の輻輳眼球運 動を制限すると相対的に融像限界が縮小したことから, 輻軼運動を行いつつ連続的, 時間的に注視点を変化させ ながら視差情報を処理していると述べている。また， Tsirlin ら（11）は，複数の視差を有する透明立体視では， 異なる 6 面まで判別できると述べている。これらの先行 研究の結果から, 中間画像の枚数が少ない状態では, そ れぞれの像面を明確に判別でき，かつ視差角は等分され て小さくなるため，各像面を順にたどることにより融像 限界が拡張する。さらに中間画像の枚数が増加していく と，個々の像面間を判別することが難しくなるが，像面 間の視差角が小さくなるため, 視差情報の処理が容易に なり, 結果として融像限界が拡張すると考えられる。本 研究では，中間画像 6 枚までは像面の判別ができている が，次第に判別が困難になっていき，「一番よく見える」 と答える実験参加者が減少していく。しかし, 中間画像 の枚数が大量（14 枚）になると, 像面の判別はできな いものの，小さな視差角を持つ多くの像面間を滑らかに たどることで，全体として大きな視差角の飛出し画像を 認識できると考えられる。

以上の結果から，初期画像のよらな，ディスプレイ面 に表示された画像と大きな視差角を持った飛出し画像を 融像することは難しいが，両者の間に立体映像の視差角 を等分する中間画像を挿入することで，等分された小さ い視差角で段階を踏んで輻輳と水晶体調節位置を合わせ ることができ, 融像限界が拡張することが推察される。

\section{3 融像限界の変化が生体に与える影響}

立体映像観視に際して生じる問題として代表的なもの は，両眼視差角と 3D 表示方式に起因する画像表示面と 輻輳焦点位置の不一致といら立体視の原理的な問題と, 左右眼の映像差（サイズ，輝度，ゆが久，位置ずれ，色 ずれ，時間ずれ）に起因する視覚愁訴の問題がある。前 者については，「調節輻輳不一致」説が一般に信じられ ていたが，共同研究者らの先行研究に扣いては，立体映 像であっても自然視状態と同様に水晶体調節焦点は仮想 映像に追随して移動していることが計測されている(13）。しかし，立体映像による生体影響（3D 酔い，視覚 疲労）の原因については，先に述べたように完全に解明 されたわけではない（12）。3DC 安全ガイドライン (4) では，時間的空間的に急な視差角変化は疲労の原因にな るので避けるのが望ましいと述べている。山賀ら（13） は，2D 映像と立体映像視聴時の比較を行って打り，交 互に視聴した際の眼球運動を測定すると輻輳角がステッ プ状に変化し，この変化に抢ける輻軑応答時間や収束特 性を分析することで視覚への影響を評価できる可能性が 
あると述べている。さらに, 立体視聴時の焦点距離と輻 輳距離の矛盾に起因する眼精疲労は, 主観的にはとら兄 ることができないくらい小さい，もしくは個人差が大き いものであったとも述べている。江本ら（14）は, 立体 画像観視に伴う融像幅の変化について, 融像幅の変動が 疲労の指標となる可能性があると報告している。これら を鑑みると, 小さな視差量を連続的に処理できる映像構 成と, 多数の視差量を持つ積層された映像を, 段階を踏 んで処理できる提示時間を確保することで, 融像限界が 拡張され，かつ疲労や視覚愁訴の発生を抑えることがで きると考えられる。一方, 連続的に注視点を移動させ， 視差情報を処理する余裕のない急激な視差角の変化, ス テップ幅の大きい複数の立体映像, などが, 視覚愁訴を 誘起しやすくなり, 融像限界の拡張を阻害する要因とな ると考えられる。

\section{6. ま と め}

本研究では飛出し量が大きくても多くの人が無理なく 見ることができる立体映像の条件を把握することを目的 とし，立体映像の視差角を等分する中間画像の挿入によ る融像限界に変化があるかを検証した。実験では, 中間 画像挿入前 - 後の融像限界の変化について, 枚数別 - 年 齢層別に比較・検証した。その結果平均 $1.3^{\circ}$ の拡張が あり, 中間画像の存在により, 飛出し量を等分した小さ い視差角で段階を踏んで輻輳と水晶体調節位置を合わせ ることができるためと考えられる（図 1)。本研究では 中間画像の枚数別抏よび年齢層別による効果に有意差は なかったが, 14 枚が最も融像限界の拡張幅が大きかっ たことから, 今後は, 融像限界が増大した際の中間画像 の枚数の違いによる見やすさも含めた検証を行ら必要が ある。また, 本研究に拈いて, 中間画像の枚数が多いほ ぞ融像限界が拡張したといら大島ら（10）の先行研究と は異なった結果が出たことは, 実験参加者が多人数にて 時間が確保できなかったことから，1枚から 14 枚の中 間画像の枚数別のらちょく見えたと回答したグループの みの計測であったことが要因と考えられる。次回の実験 ではすべての実験参加者での計測を行う予定である。

\section{謝 辞}

本研究を進めるに当たり, 実験にご協力くださいまし た実験参加者の皆様をはじめ, 関係者の皆様に深く感謝 申乙上げます。本研究はJSPS 科研費 24300046 及び 243300032 の助成を受けたものである。
利益相反はありません。

\section{文献}

（1）小嶌健仁．製品の安全基準と生体影響リスク一3D 立 体映像のガイドライン規制を例にして一，社会医学研 究 2014;31(1):69-79.

(2) 吉川一輝, 大橋拓実, 小嶌健仁, 本多悠真, 石尾広武, 高田真澄, 大森正子, 宮尾 克. 立体映像の飛出し認 知限界に関する研究. 日本衛生学雑誌 2016;71:1-7.

(3) 塩見友樹, 堀 弘樹, 長谷川聡, 高田宗樹, 大森正子, 松浦康之, 石尾広武, 長谷川旭, 神田哲也, 宮尾 克. 実物体と 2D 映像，3D 映像を用いた水晶体調節反応 と輻輳運動の長時間同時測定，若年者と中高齢者の立 体視機構の違い.日本バーチャルリアリティ学会論文 誌 2011;16(2):139-148.

(4) MacKenzie KJ, Hoffman DM, Watt SJ. Accommodation to multiple-focal-plane displays. Implications for improving stereoscopic displays and for accommodation control. J Vis 2010;10(8):22. doi:10.1167/10.8.22.

（5）小嶌健仁. 3D 立体映像の視認性と生体映像に関する 研究. 名古屋大学 2014 ; 博士学位論文.

（6） 3D コンソーシアム安全ガイドライン部会. 人に優し い3D 普及のための 3DC 安全ガイドライン. 2010.

（7）江本正喜, 矢野澄男, 長田昌次郎. 立体画像システム 観察時の融像限界の分布. 映像メディア学会誌 2001;55(5):703-710.

（８）長田昌次郎。立体映像の観視時に打ける輻輳性融合立 体視限界 VFSL の分布. 日本バーチャルリアリティ学 会論文誌 2002;7(2):239-246.

（9）奈良信雄（監修）. 人体のしくみと病気. 西東社, 2015, 60-61.

（10）大島敦之, 佐伯 諭, 森 峰生, 大頭 仁. 両眼立体 視に抢ける視差情報の処理機構. VISION 1999;11(2): 93-96.

(11) Tsirlin I, Allison RS, Wilcox LM. Stereoscopic transparency constraints on the perception of multiple surfaces. J Vis 2008;8(5):5.1-10.

(12）3D テレビに関する検討会最終報告書. 2012.10.3D テ レビに関する検討会

（13）山賀達也, 吉澤 誠, 杉田典大, 阿部 誠, 本間経康. 3D 映像視聴における焦点距離と輻輳距離の矛盾が生 体に与学る評価, 計測自動制御学会東北支部第 287 回 研究集会 2014 ; 資料番号：297-10.

（14）江本正喜, 矢野澄男. 立体画像観視に伴ら融像幅の変 化, 電子情報学会画像工学研究会信学技報 2000 ; EID99-139. 